\title{
アルミニウム合金板上に形成させた $\mathrm{TiO}_{2}$ 薄膜の 光触媒活性に対する陽極酸化皮膜の影響
}

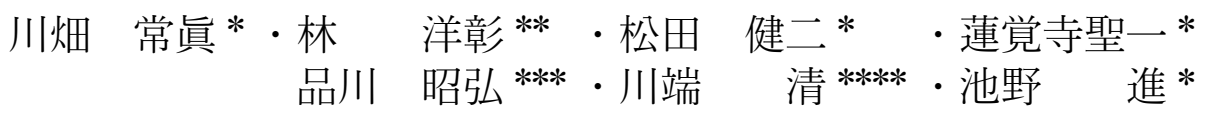

\section{The effect of anodic oxide film on photo catalysis of $\mathrm{TiO}_{2}$ thin film formed on aluminum alloy sheets}

\author{
Tokimasa KAWABATA*, Hiroaki HAYASHI**, Kenji MATSUDA*, Seiichi RENGAKUJI* \\ Akihiro SHINAGAWA***, Kiyoshi KAWABATA**** and Susumu IKENO*
}

\begin{abstract}
The photocatalytic activity of $\mathrm{TiO}_{2}$ thin film formed on 5083 aluminum alloy $\left(\mathrm{TiO}_{2} / 5083\right)$ sheets by using the advanced sol-gel method, and the effect of anodic oxide film between $\mathrm{TiO}_{2}$ thin film and 5083 alloy sheets were investigated by evolution of photocatalytic activity, X-ray diffraction (XRD) technique, transmission electron microscopy (TEM), energy dispersive spectroscopy (EDS) and scanning electron microscopy (SEM). The photocatalytic activity of $\mathrm{TiO}_{2} / 5083$ sheet was low and $\mathrm{MgO}$ was detected by XRD and TEM. The photocatalytic activity of $\mathrm{TiO}_{2} / 5083$ sheet with anodic oxide was improved and was higher than that of $\mathrm{TiO}_{2} / 5083$ sheet without anodic oxide film. It was confirmed by XRD, SEM and high resolution TEM that $\mathrm{MgO}$ was not detected in the $\mathrm{TiO}_{2}$ thin film with anodic oxide film between $\mathrm{TiO}_{2}$ thin film and 5083 sheet. It has been considered that the sheet which has anodic oxide film between $\mathrm{TiO}_{2}$ and 5083 sheet did not have $\mathrm{MgO}$.
\end{abstract}

(Received August 25, 2003)

Keyzords: photo catalysis, $\mathrm{TiO}_{2}$, anodic oxide film, 5083 aluminum alloy

\section{1. 緒言}

著者らは1), 2), 高い光触媒活性を有する $\mathrm{TiO}_{2}$ 薄膜を得る方 法として，従来のゾルーゲル法を改良した新規な薄膜作製法 を開発し，この方法をアドバンスト・ゾルーゲル法と呼んで いる。この方法は, 疎水性溶媒と親水性溶媒をある比率で混 ぜた溶媒中に金属アルコキシドを溶解し, 加水分解, 重縮合 を制御したものを前駆体溶液として成膜し，焼成する方法で ある。この方法でガラスおよびセラミックス基板に作製した $\mathrm{TiO}_{2}$ 薄膜は良好な密着性を有し, 光触媒活性が従来の $\mathrm{TiO}_{2}$ 薄膜や $\mathrm{TiO}_{2}$ 粉末添加膜に比べて，非常に優れていることを 見出している3）。また，この方法において，基板を $99.99 \%$ ア ルミニウム（以下純 $\mathrm{Al}$ と称す）としたものは，特に高活性 を示すこともわかっている4)。

しかし，実用合金のうち，5083アルミニウム合金（以下 5083 合金と称す。その他のアルミニウム合金に関しても，同 様とする）や 7075 合金を基板とした場合，特に 5083 合金で

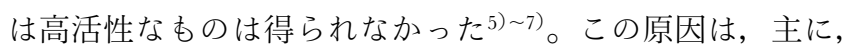

薄膜中に合金成分の一部，特に $\mathrm{Mg}$ が溶出するためと思われ る。そこで, 本研究では, 活性の低かった 5083 合金を陽極 酸化し, 中間層として陽極酸化皮膜を形成させ，この皮膜上 にアドバンスト・ゾルーゲル法を適用して $\mathrm{TiO}_{2}$ を成膜し, こ のものの光触媒活性を調べた。

\section{2. 実験方法}

\section{1 基板の調整および陽極酸化皮膜の形成条件}

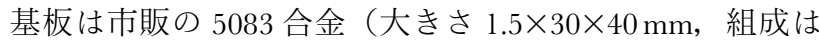
Table 1 参照）を， $\mathrm{H}_{2} \mathrm{SO}_{4}$ 浴中で陽極酸化したものとした。 陽極酸化条件は， $\mathrm{H}_{2} \mathrm{SO}_{4}$ 濃度 $15 \mathrm{vol}^{\%} \%$, 浴温度 $293 \mathrm{~K}$, 電流 密度 $5 \mathrm{~A} \cdot \mathrm{m}^{-2}$ で対極はアルミニウムである。なお，封孔処理

Table 1 Chemical composition of 5083 aluminum alloy

$(\operatorname{mass} \%)$

\begin{tabular}{c|c|c|c|c|c|c|c|c|c}
\hline \hline $\mathrm{Si}$ & $\mathrm{Fe}$ & $\mathrm{Cu}$ & $\mathrm{Mn}$ & $\mathrm{Mg}$ & $\mathrm{Cr}$ & $\mathrm{Zn}$ & $\mathrm{Ti}$ & $\mathrm{Zr}$ & $\mathrm{Al}$ \\
\hline 0.099 & 0.233 & 0.028 & 0.624 & 4.400 & 0.086 & 0.011 & 0.028 & - & bal. \\
\hline
\end{tabular}

*富山大学工学部物質生命システム工学科（广 930-8555 富山県富山市五福 3190)。Department of System Engineering for Material and Life Science, Faculty of Engineering, Toyama University (3190 Gofuku, Toyama-shi, Toyama 930-8555).

**富山大学大学院理工学研究科 (富山市) [現在：日本高周波鋼業(侏)（富山市）］。Graduate School of Science and Engineering, Faculty of Engineering, Toyama University (Toyama-shi, Toyama) [Present: NIPPON KOSHUHA STEEL CO., LTD. (Toyama-shi, Toyama)].

****日本カーリット(樕（渋川市)。Japan Carlit Co., Ltd.（Shibukawa-shi, Gunma）.

***** 新日軽(㑣)（高岡市）。SHIN NIKKEI COMPANY, LTD (Takaoka-shi, Toyama). 

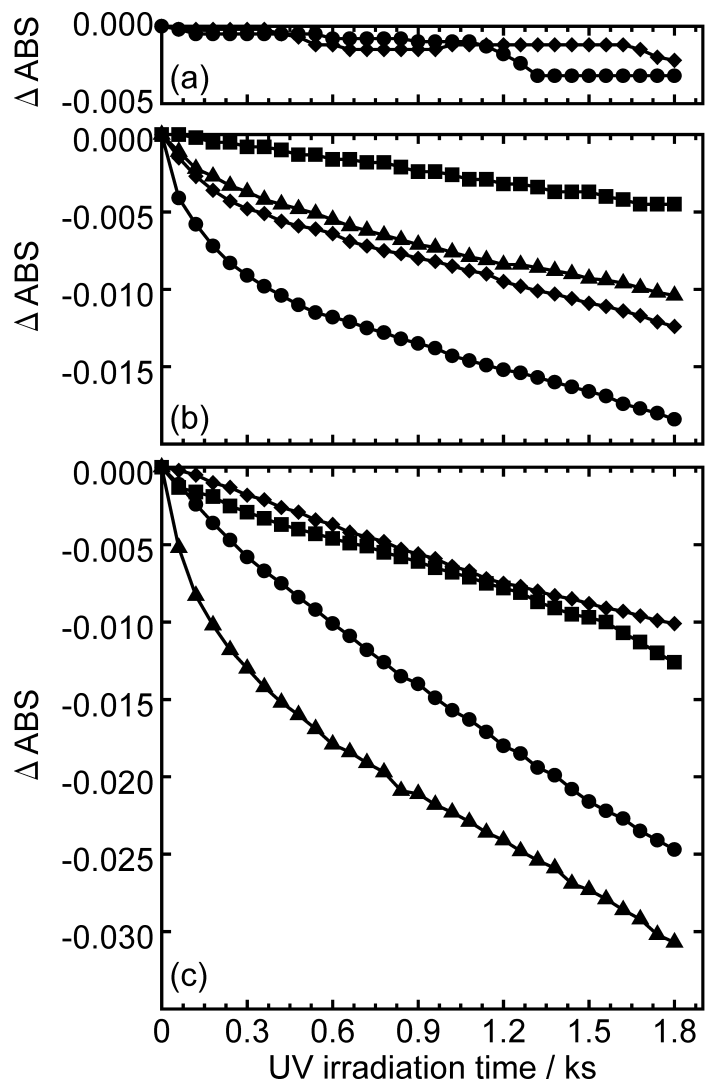
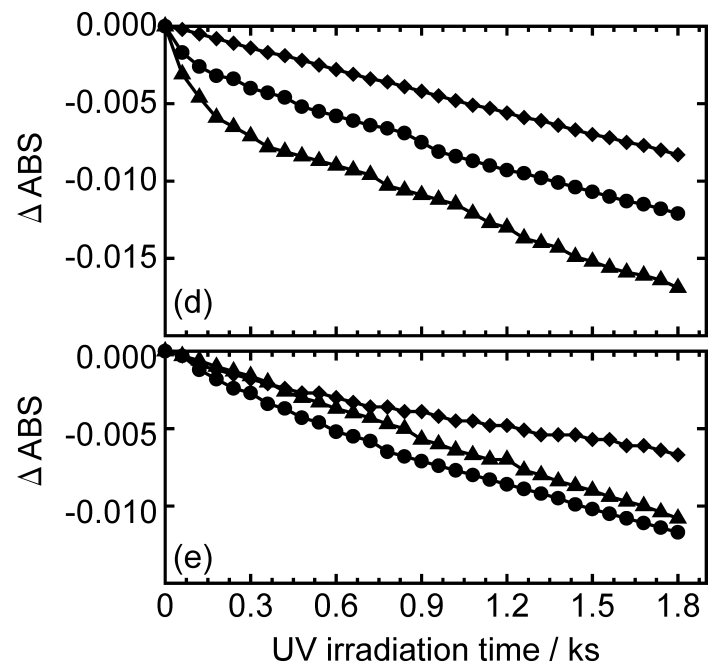

Fig. 1 Change of absorbance in the $\mathrm{TiO}_{2}$ thin film on 5083 aluminum alloy sheets formed anodic oxide film. The thickness of anodic oxide films are (a) 0, (b) 1, (c) 5, (d) 11 and (e) $18 \mu \mathrm{m}$. Sintering conditions are $623 \mathrm{~K}(\diamond), 673 \mathrm{~K}$ $(\bullet), 723 \mathrm{~K}(\boldsymbol{\Delta})$ and $773 \mathrm{~K}(\boldsymbol{\square})$ for $3.6 \mathrm{ks}$.

\section{は行っていない。}

\section{2 酸化チタン前駆体溶液の調整}

$\mathrm{TiO}_{2}$ 成膜のための前駆体溶液としては, チタン (IV) n-ブ トキシド・モノマー $34 \mathrm{ml}$ をベンゼン $166 \mathrm{ml}$ に溶解させ, 8 時間の還流を行った後, 加水分解を促進させるためにn-ブ夕 ノールに $5 \%$ の水を溶解させた含水ブタノールを加え, 再び 8 時間の還流を行った後, 濃縮し, ベンゼンで希釈して, チ タン濃度を $1.0 \mathrm{~mol} \cdot \mathrm{dm}^{-3}$ に調整したものを用いた。

\section{3 酸化チタン薄膜の形成}

成膜は，この前駆体溶液中に基板を浸漬して，0.6 ks 溶液 中で保持した後，ディップコーティング法8) で行った。この ときの引き上げ速度は $0.165 \mathrm{~mm} \cdot \mathrm{s}^{-1}$ である。最後に, この成 膜試料を大気中, 温度を $623 \sim 773 \mathrm{~K}$ の範囲で变化させて焼 成した。

\section{4 光触媒活性の評価方法}

作製した試料の光触媒活性評価は，作製試料を $1 \mathrm{mmol} \cdot \mathrm{l}^{-1}$ のメチレンブルー水溶液に $1.8 \mathrm{ks}$ 浸漬後, 約 $323 \mathrm{~K}$ で大気炉 中にて乾燥あるいは焼成したものに対して，紫外線を照射し て行った。使用した装置は, 光触媒評価チェッカーPCG-1 で ある。このときの紫外線強度は約 $1 \mathrm{~mW}$ である。この評価方

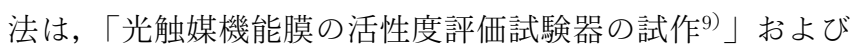
「防污活性用光触媒チェッカーによる測定例10)」によるもの で, 紫外線照射による, メチレンブルーの分解を吸光度変化 （以後 $\triangle \mathrm{ABS}$ と称する）で評価する方法である。

\section{5 薄膜の観察および分析}

得られた薄膜のキャラクタリゼーションは薄膜 X 線回折測 定, 走査型電子顕微鏡 $(\mathrm{SEM})$ および透過型電子顕微鏡
（TEM）観察などにより行った。

\section{3. 実験結果および考察}

\section{1 光触媒活性の評価}

光触媒活性の評価結果を Fig. 1(a)〜（e）に示す。（a）は 5083 合金基板に直接 $\mathrm{TiO}_{2}$ 薄膜を作製した試料の結果で (b) ～(e) は $\mathrm{TiO}_{2}$ 薄膜と母材との間に陽極酸化皮膜を形成さ せた試料の結果である。陽極酸化皮膜の厚さは Fig. 1(b) で は $1 \mu \mathrm{m}, （ \mathrm{c})$ では $5 \mu \mathrm{m}$ ，（d）では $11 \mu \mathrm{m}$ および（e）では $18 \mu \mathrm{m}$ である。なお，暗所ではいずれの試料においても， $1.8 \mathrm{ks}$ 後, $\Delta \mathrm{ABS}$ の変化は認められなかった。5083 合金基板 上に直接 $\mathrm{TiO}_{2}$ 薄膜を塗布した試料では（Fig. 1(a)），623 お よび $673 \mathrm{~K}$ のいずれの温度で焼成した試料においても， $\Delta \mathrm{ABS}$ がほとんど变化しておらず，光触媒活性がほとんど 認められない。陽極酸化皮膜を形成させた試料では (Fig. 1(b)〜 (e))， $\Delta \mathrm{ABS}$ が照射時間とと屯に明らかに減少し ており，いずれの試料においても光触媒活性が発現している のがわかる。また， $1 \mu \mathrm{m}$ 厚さの陽極酸化皮膜を有する試料 の結果では（Fig. 1(b)），673K で焼成した試料において， $\triangle \mathrm{ABS}$ の変化が最も大きく, それより焼成温度が高くても低 くても $\triangle \mathrm{ABS}$ の変化量が小さくなる傾向が見られる。この 傾向は純 $\mathrm{Al}$ 基板に直接 $\mathrm{TiO}_{2}$ 薄膜を形成したときの結果と 類似している ${ }^{4)}$ 。陽極酸化皮膜の厚さを $5 \mu \mathrm{m}$ とすると (Fig. 1(c))，723K で焼成した試料が最も $\Delta \mathrm{ABS}$ の低下が大 きく，皮膜の厚さが $5 \mu \mathrm{m}$ よりも厚い $11 \mu \mathrm{m}$ （Fig. 1(d)）お よび $18 \mu \mathrm{m}$ （Fig. 1(e)）では， $5 \mu \mathrm{m}$ のときよりも変化量が小 さくなっている。このように，本実験の焼成条件下では，陽 


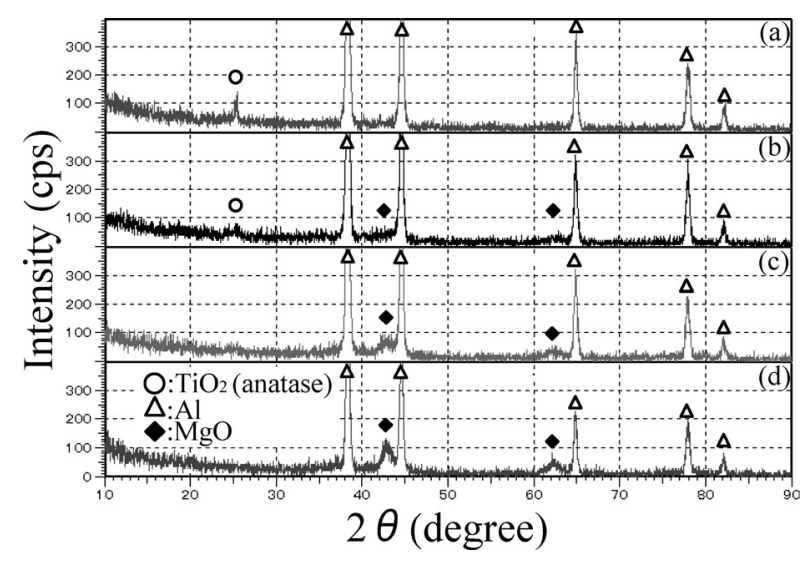

Fig. 2 X-ray diffraction patterns of $\mathrm{TiO}_{2}$ thin films on 5083 aluminum alloy sheets sintered at (a) 623, (b) 673, (c) 723 and (d) $773 \mathrm{~K}$ for $3.6 \mathrm{ks.}$

極酸化皮膜の厚さが $11 \mu \mathrm{m}$ 以上になると光触媒活性が低下す る傾向にあった。しかし，陽極酸化皮膜を形成させることに より 5083 合金基板上に形成した $\mathrm{TiO}_{2}$ 薄膜の光触媒活性が向 上することがわかったので，陽極酸化皮膜の有無によってど のような変化が生じているのかを次に調べた。

\section{2 陽極酸化皮膜を形成していない試料における金属酸 化物薄膜の微細構造}

Fig. 2 は 5083 合金基板に直接 $\mathrm{TiO}_{2}$ 薄膜を形成させた試料 の結晶性を薄膜 X 線回折装置によって調べた結果である。焼 成温度を $623 \mathrm{~K}$ とした試料では（a）に見られるように， $2 \theta=25.3^{\circ}$ 付近に $\mathrm{TiO}_{2}$ のアナターゼに相当するピーク（○印） が出現している。このピークは焼成温度が $673 \mathrm{~K}$ でも認めら れるが，ピーク強度は低下している（Fig. 2(b))。さらに, $723 \mathrm{~K}$ では，ピークはほとんど認められなくなり，773K では 消失している（Fig. 2(c)，(d）参照)。これに対して焼成温 度が $673 \mathrm{~K}$ あたりから， $\mathrm{MgO}$ に相当すると思われるピークが 認められ始め, 焼成温度の上昇とと屯に明瞭になっている。 これは, 5083 合金基板中の $\mathrm{Mg}$ が $\mathrm{TiO}_{2}$ 薄膜に拡散して, $\mathrm{MgO}$ が生成したためと思われる。

Fig. 3 は, Fig. 2(b) の試料の断面 SEM 像と EDS による 線分析の結果である。（a）のSEM 像に打ける左側の暗く見 える部分は 5083 合金基板であり, 灰色の部分が $\mathrm{TiO}_{2}$ 薄膜之 思われる部分である。（b）の EDS による線分析の結果から， （a）中の破線内に相当する領域からは非常に高い $\mathrm{Mg}$ と $\mathrm{O}$ が 検出されたのに比較して, Tiのピークは大变低かった。この ことは, Fig. 2(b) の XRD 測定でアナターゼのピークが低 かったことに一致する。Fig. 2 と Fig. 3 から合金成分の $\mathrm{Mg}$ が $\mathrm{TiO}_{2}$ 膜中に拡散し, $\mathrm{MgO}$ の生成が示唆されたので, SEM 観察したものと同条件で作製した試料を $10 \% \mathrm{NaOH}$ 水溶液 中に浸して 5083 合金基板のみを溶解し, 取出した $\mathrm{TiO}_{2}$ 薄膜 を TEM 観察した結果を Fig. 4 に示す。Fig. 4(a) に HRTEM 像を示すが，薄膜は約 $10 \mathrm{~nm}$ 程度の非常に微細な結晶粒で構 成され，その中に $0.243 \mathrm{~nm}$ 間隔の格子縞が見られる。この格 子縞間隔の值は $\mathrm{MgO}$ の（111）面間隔に一致した。Fig. 4(b) は制限視野回折図形であるが， $\mathrm{MgO}$ として解析できる回折 リングが観察された。図は省略したが，TEM 観察した薄膜 から得た EDS プロファイルにおいてはTi れなかった。 (a)

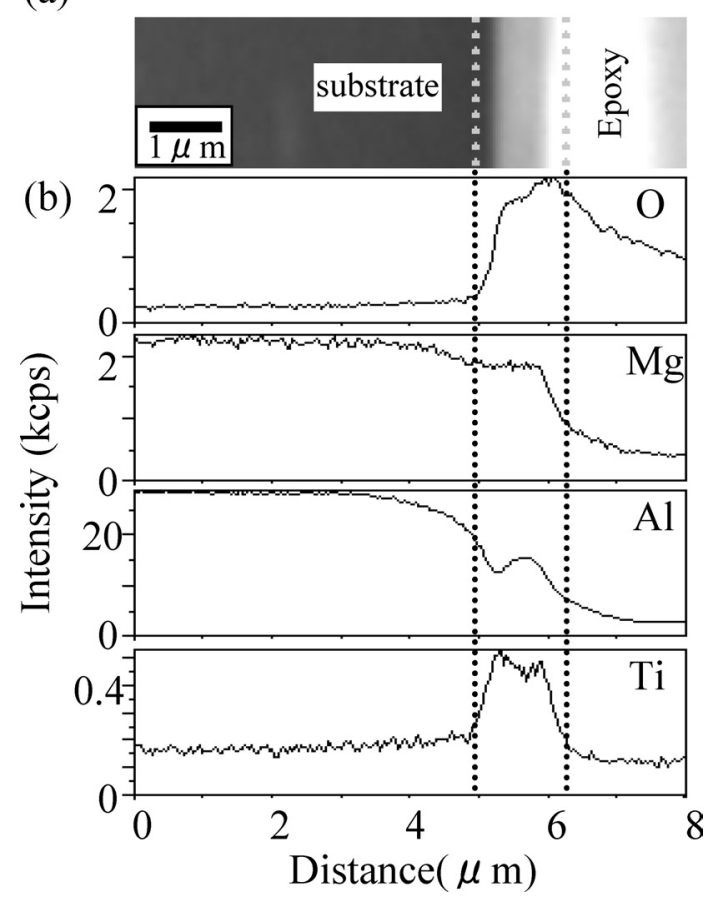

Fig. 3 EDS line analysis of interface between $\mathrm{TiO}_{2}$ and 5083 aluminum alloy sheets sintered at $673 \mathrm{~K}$ for $3.6 \mathrm{ks}$ : (a) SEM cross section image and (b) EDS line analysis.

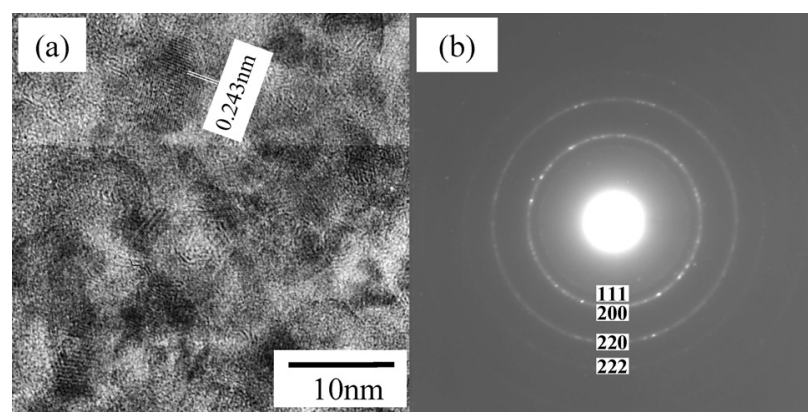

Fig. 4 TEM image of thin film formed on 5083 aluminum alloy sheet sintered at $673 \mathrm{~K}$ for $3.6 \mathrm{ks}$ : (a) HRTEM image and (b) electron diffraction pattern.

以上の結果から，合金基板中の $\mathrm{Mg}$ が焼成を行うことに よって基板に塗布された膜に侵入して，膜中の酸素と反応す ることによって $\mathrm{MgO}$ が形成されっこれが $\mathrm{TiO}_{2}$ の光触媒活性 を低下させる原因と考えられる。また, $\mathrm{MgO}$ が形成するこ とに付随して, $\mathrm{Ti}_{\mathrm{n}} \mathrm{O}_{2 \mathrm{n}-1}$ のような低次の酸化チタンが形成し, 膜中に存在していることも考えられるが11), 今回の結果から はそれらに相当する明瞭な証拠は得られなかったため, 存在 するとしてもその影響は非常に低いと考えられた。この TEM 観察の結果は, Fig. 2 のRD 測定において, 焼成温度が高 くなると $\mathrm{MgO}$ のピークが強くなることからも示唆される。

\section{3 陽極酸化皮膜を形成した試料における金属酸化物薄 \\ 膜の微細構造}

Fig. 5 は 5083 合金基板と $\mathrm{TiO}_{2}$ 薄膜の間に $5 \mu \mathrm{m}$ 厚さの陽 極酸化皮膜を介在させた試料の X 線測定の結果である。ここ で特徵的なのは，いずれの焼成条件においても Fig. 2(d) で 明瞭にみられた $\mathrm{MgO}$ のピークが一切みられないことである。 Fig. 5(a) では明瞭ではないが, 焼成温度が $673 \mathrm{~K}$ 以上で 


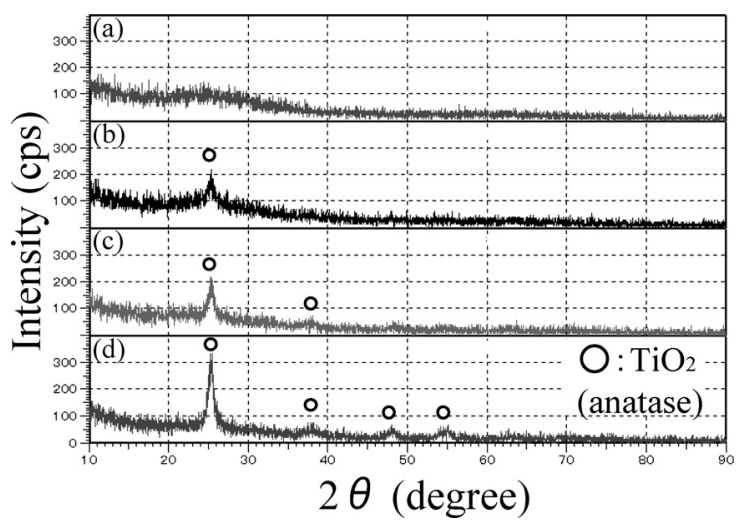

Fig. 5 X-ray diffraction pattern of $\mathrm{TiO}_{2}$ thin films on 5083 aluminum alloy sheets formed anodic oxide film (the thickness of $5 \mu \mathrm{m}$ ) sintered at (a) 623, (b) 673, (c) 723 and (d) $773 \mathrm{~K}$ for $3.6 \mathrm{ks}$.

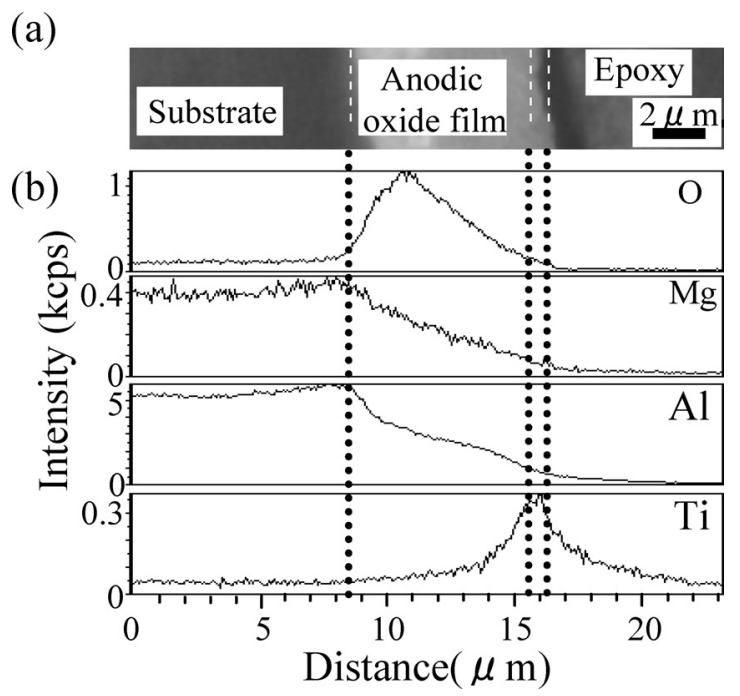

Fig. 6 EDS analysis of interface between $\mathrm{TiO}_{2}$ film and 5083 aluminum alloy sheet formed anodic oxide film (the thickness of $5 \mu \mathrm{m}$ ) sintered at $673 \mathrm{~K}$ for $3.6 \mathrm{ks}$ : (a) SEM cross section image and (b) EDS line analysis.

は Fig. 5(b) から（d）に見られるごとく，明らかにアナター ゼ構造の $\mathrm{TiO}_{2}$ からのピークがみられ, そのピーク強度は焼 成温度が高いほど強い傾向にある。このように, $\mathrm{TiO}_{2}$ のアナ ターゼに基づくピークが不明瞭に認められる温度領域から明 瞭に認められる温度領域に至るまで光触媒活性が発現すると いう結果は, 純アルミニウム基板に直接に $\mathrm{TiO}_{2}$ 薄膜を形成 させたときの結果と類似している ${ }^{4)}$ 。

Fig. 6 は Fig. 5(b) の試料の断面の（a）SEM 像および（b） EDS による線分析の結果である。（b）からわかるように，陽 極酸化皮膜表面部分に $\mathrm{TiO}_{2}$ 薄膜の存在が認められるが，そ の部分では $\mathrm{Mg}$ の濃度は非常に低くなっている。

Fig. 7 は Fig. 4 の試料之同様の操作によって $\mathrm{TiO}_{2}$ 薄膜の みを取出し, TEM 観察した結果である。（a）の TEM 明視野 像からむ Fig. 4(a) と同様に, $10 \mathrm{~nm}$ 程度の微細な結晶粒が 観察されている。写真中には $\mathrm{TiO}_{2}$ のアナターゼ構造におけ る（101）面に相当する間隔の格子縞が観察されており，(b) の制限視野回折像でも, $\mathrm{TiO}_{2}$ のアナターゼ構造に相当する 回折リングが観察された。したがって, 陽極酸化皮膜を形成

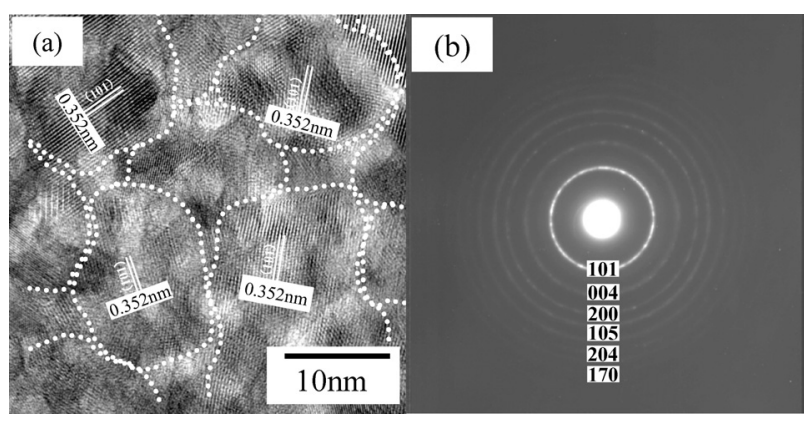

Fig. 7 TEM image of thin film on 5083 aluminum alloy sheet formed anodic oxide film (the thickness $5 \mu \mathrm{m}$ ) sintered at $673 \mathrm{~K}$ for $3.6 \mathrm{ks}$ : (a) HRTEM image and (b) electron diffraction pattern.

させることで $\mathrm{TiO}_{2}$ 膜中への $\mathrm{Mg}$ の拡散が抑制されると考え られる。

\section{4 形成した金属酸化物薄膜の生成エネルギーの検討}

$\mathrm{TiO}_{2}$ および $\mathrm{MgO}$ の生成エネルギー $\Delta \mathrm{G}_{\mathrm{T}}^{\circ}$ を比較し, 各金 属の酸化されやすさを検討した。今回の焼成温度範囲 （623７73 K）において， $\mathrm{Ti}$ および $\mathrm{Mg}$ はそれぞれ次の酸化還 元反応を起こすと考えられる ${ }^{12)}$ 。

$$
\begin{aligned}
& \mathrm{Ti}(\mathrm{s})+\mathrm{O}_{2}(\mathrm{~g})=\mathrm{TiO}_{2}(\mathrm{~s}) \\
& 2 \mathrm{Mg}(\mathrm{s})+\mathrm{O}_{2}(\mathrm{~g})=2 \mathrm{MgO}(\mathrm{s})
\end{aligned}
$$

ここで，（s）は固体，（g）は気体状態をそれぞれ示す。これ らの反応から温度 $\mathrm{T}[\mathrm{K}]$ における標準生成自由エネルギー $\Delta \mathrm{G}_{\mathrm{T}}^{\circ}$ は $\mathrm{TiO}_{2}$ および $\mathrm{MgO}$ においてそれぞれ，

$$
\begin{aligned}
& \mathrm{TiO}_{2}: \Delta \mathrm{G}_{\mathrm{T}}^{\circ}=-935100+173.8 \mathrm{~T} \\
& \mathrm{MgO}: \Delta \mathrm{G}_{\mathrm{T}}^{\circ}=-1208000-24.6 \mathrm{~T} \cdot \log \mathrm{T}+284 \mathrm{~T}
\end{aligned}
$$

で与えられる ${ }^{12)}$ 。これらの式から 623 と $773 \mathrm{~K}$ における $\Delta \mathrm{G}_{\mathrm{T}}^{\circ}$ を算出すると，

$$
\begin{aligned}
\mathrm{TiO}_{2}: \Delta \mathrm{G}_{\mathrm{T}=623 \mathrm{~K}}^{\circ} & =-826823 \mathrm{~J} \cdot \mathrm{mol}^{-1} \cdot \mathrm{K}^{-1}, \\
\Delta \mathrm{G}_{\mathrm{T}=773 \mathrm{~K}}^{\circ} & =-800753 \mathrm{~J} \cdot \mathrm{mol}^{-1} \cdot \mathrm{K}^{-1} \\
\mathrm{MgO}: \Delta \mathrm{G}_{\mathrm{T}=623 \mathrm{~K}}^{\circ} & =-1073896 \mathrm{~J} \cdot \mathrm{mol}^{-1} \cdot \mathrm{K}^{-1}, \\
\Delta \mathrm{G}_{\mathrm{T}=773 \mathrm{~K}}^{\circ} & =-1043389 \mathrm{~J} \cdot \mathrm{mol}^{-1} \cdot \mathrm{K}^{-1}
\end{aligned}
$$

となる。いずれの温度においても $\mathrm{TiO}_{2}$ と比較し $\mathrm{MgO}$ の方が $\Delta \mathrm{G}^{\circ}$ の負の絶対值が大きく, 式（1）よりも式（2）の反応の 起こる傾向が大きいのがわかる。すなわち, $\mathrm{TiO}_{2}$ よりも $\mathrm{MgO}$ の方が今回の焼成温度において, 安定であることがわかる。

以上のことから，基板と $\mathrm{TiO}_{2}$ 薄膜との中間に陽極酸化皮 膜を形成させることにより，基板中の $\mathrm{Mg}$ の $\mathrm{TiO}_{2}$ 薄膜中へ の侵入を防止することができ，これによって光触媒活性の低 下を防止できるといえる。

ただし，Fig. 1（b)〜（e）でわかるように，陽極酸化皮膜が 厚い場合には $\triangle \mathrm{ABS}$ の減少割合が低下した原因については現 段階では明確ではない。しかし, 試料表面のSEM 観察にお いて違いが見出された。Fig. 8(a) の陽極酸化皮膜が $1 \mu \mathrm{m}$ の 厚さでは下地の 5083 合金表面の凹凸が観察されている。陽 極酸化皮膜の厚みが 5,11 および $18 \mu \mathrm{m}$ と増加するに従い, 


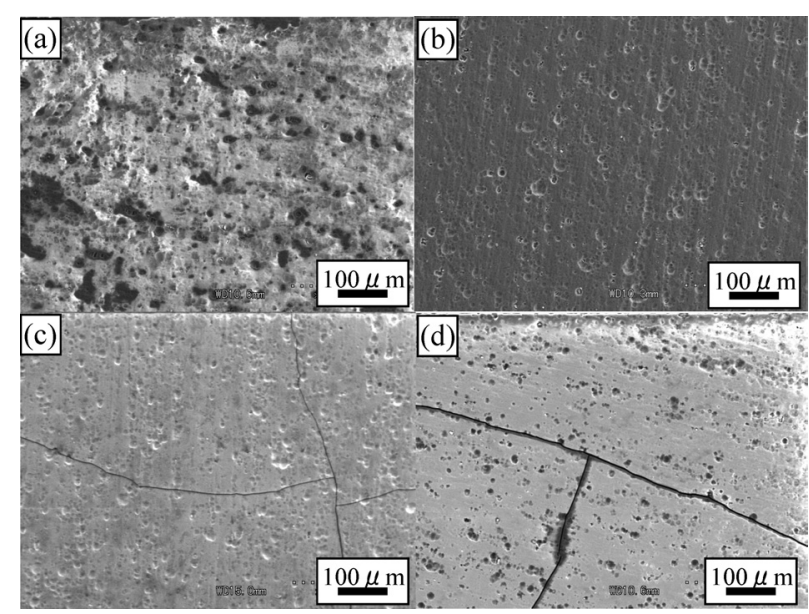

Fig. 8 SEM images of $\mathrm{TiO}_{2}$ thin film on 5083 aluminum alloy sheets formed anodic oxide film sintered at $673 \mathrm{~K}$ for $3.6 \mathrm{ks}$. The thickness of anodic oxide films are (a) 1 , (b) 5, (c) 11 and (d) $18 \mu \mathrm{m}$.

（b），(c) および（d）に見られるように，次第に滑らかな表 面となる傾向にあったが，11 打よび $18 \mu \mathrm{m}$ になると（c）お よび（d）に示したようなクラックが試料全面にわたって観 察された。このクラックは $\mathrm{TiO}_{2}$ を塗布して焼成した後に確 認されていることから, 焼成時の加熱 - 冷却過程で $\mathrm{TiO}_{2}$, 陽 極酸化皮膜抢よび 5083 合金の熱膨張率の違いによって生じ たものと考えられ，このような試料表面の欠陥が $\mathrm{TiO}_{2}$ 膜の 分布を不均一にしていることで, $\Delta \mathrm{ABS}$ の減少割合が低下し たのではないかと推察している。

\section{4. 結言}

5083 合金基板に形成した $\mathrm{TiO}_{2}$ の光触媒活性および陽極酸 化皮膜の影響について調べた結果，以下のことがわかった。

（1） 5083 合金基板に直接 $\mathrm{TiO}_{2}$ 薄膜を形成した試料の光触

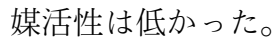

（2）5083 合金基板に陽極酸化皮膜を形成した試料の光触 媒活性は, 5083 合金基板に直接 $\mathrm{TiO}_{2}$ 薄膜を形成した試料と
比較し，明らかに向上した。

（3）X線回折，TEM観察㧍よび SEM-EDS による元素分 析の結果より 5083 合金板中のマグネシウムが $\mathrm{TiO}_{2}$ 薄膜に侵 入して酸素之反応し, $\mathrm{MgO}$ が形成され, 光触媒活性が低下 すると考えられた。これは $\mathrm{MgO}$ の標準生成自由エネルギー の值が $\mathrm{TiO}_{2}$ のそれよりも低いことからも裏付けられた。し かし, $\mathrm{TiO}_{2}$ 薄膜を形成する前に 5083 合金基板表面に陽極酸 化皮膜を形成させることによって，これを防止できることが わかった。

（4）陽極酸化皮膜を形成した後に $\mathrm{TiO}_{2}$ 薄膜を作製した 5083 合金基板試料の光触媒活性は，陽極酸化皮膜の厚さお よび焼成条件に依存し，良好な光触媒活性を得るための適切 な条件が存在した。

\section{参 考 文 献}

1）蓮覚寺聖一, 袖澤真吾, 中村優子, 山田明文：技術教育論文誌, 9 (2000), 29.

2）蓮党寺聖一, 中村優子, 川畑常眞, 松田健二, 池野 進：軽 金属学会第 100 回春期大会講演概要（2001），81.

3）蓮覚寺聖一, 中村優子：軽金属, 52 (2002), 38 .

4) S. Ikeno, T. Kawabata, H. Hayashi, K. Matsuda, S. Rengakuji, T. Suzuki, Y. Hatano and K. Tanaka: Materials Transactions, Vol. 43, No. 5 (2002), pp. 939.

5）林 洋彰, 蓮覚寺聖一, 川畑常眞, 松田健二, 田中克芳, 池野 進：軽金属学会第 100 回春期大会講演概要（2001），83.

6）川烟常眞, 松田健二, 蓮覚寺聖一, 田中克芳, 林 洋彰, 池野 進：軽金属学会第 100 回春期大会講演概要（2001），85.

7）川畑常眞, 林 洋彰, 松田健二, 蓮覚寺聖一, 品川昭弘, 田中 克芳, 川端清, 池野 進 : 軽金属学会第 102 回春期大会講演 概要 (2002), 167.

8）橋本和仁，藤嶋 昭：酸化チタン光触媒のすべて，(粦シーエム シー (1999), 105.

9）高崎洋一，前園明一：光機能材料研究会第 5 回光触媒シンポジ ウム予稿集 $(1998), 148$.

10）高崎洋一, 石川淳一, 前園明一: 光機能材料研究会第 6 回光触 媒シンポジゥム予稿集（1999），170.

11) Tsukasa Torimoto, Robert J. Fox, and Marye Anne Fox: J. Electrochem. Soc., 143 (1996), 3712.

12）金属物理化学，日本金属学会（1992），64. 